\title{
Off-axis symbiosis found: characterization and biogeography of bacterial symbionts of Bathymodiolus mussels from Lost City hydrothermal vents
}

\section{Citation}

DeChaine, Eric G., Amanda E. Bates, Timothy M. Shank, and Colleen M. Cavanaugh. 2006. "Off-Axis Symbiosis Found: Characterization and Biogeography of Bacterial Symbionts of Bathymodiolus Mussels from Lost City Hydrothermal Vents." Environ Microbiol 8 (11) (November): 1902-1912. doi:10.1111/j.1462-2920.2005.01113.x.

\section{Published Version}

doi:10.1111/j.1462-2920.2005.01113.x

\section{Permanent link}

http://nrs.harvard.edu/urn-3:HUL.InstRepos:14368996

\section{Terms of Use}

This article was downloaded from Harvard University's DASH repository, and is made available under the terms and conditions applicable to Other Posted Material, as set forth at http:// nrs.harvard.edu/urn-3:HUL.InstRepos:dash.current.terms-of-use\#LAA

\section{Share Your Story}

The Harvard community has made this article openly available.

Please share how this access benefits you. Submit a story. 
1 Off-axis Symbiosis Found: Characterization and Biogeography of Bacterial

2 Symbionts of Bathymodiolus Mussels from Lost City Hydrothermal Vents

3

4 DeChaine ${ }^{1}$, E. G., A. E. Bates ${ }^{2}$, T. M. Shank ${ }^{3}$, \& C. M. Cavanaugh ${ }^{1 *}$

5

$6 \quad{ }^{1}$ Department of Organismic and Evolutionary Biology, Harvard University, 16 Divinity

7 Ave., Biolabs 4081, Cambridge, Massachusetts, 02138, USA

$8 \quad{ }^{2}$ Department of Biology, University of Victoria, Victoria, V8W2Y2, CA

$9{ }^{3}$ Biology Department, Woods Hole Oceanographic Institute, Woods Hole,

10 Massachusetts, 02543, USA

11 *Corresponding author. Tel: (617) 495-2177; Fax: (617) 496-6933; E-Mail:

12 cavanaug@fas.harvard.edu

13

14 Keywords: bacterial biogeography, Bathymodiolus mussels, chemoautotroph, deep-sea

15 hydrothermal vents, endosymbionts, methanotroph

16

17 Running title: Biogeography of Lost City Symbionts 
Summary

Organisms at hydrothermal vents inhabit discontinuous chemical "islands" along

21 mid-ocean ridges, a scenario that may promote genetic divergence among populations.

22 The 2003 discovery of mussels at the Lost City Hydrothermal Field provided a means of

23 evaluating factors that govern the biogeography of symbiotic bacteria in the deep-sea.

24 The unusual chemical composition of vent fluids, the remote location, and paucity of

25 characteristic vent macrofauna at the site, raised the question of whether microbial

26 symbioses existed at the extraordinary Lost City. And if so, how did symbiotic bacteria

27 therein relate to those hosted by invertebrates at the closest known hydrothermal vents

28 along the Mid-Atlantic Ridge (MAR)? To answer these questions, we performed

29 microscopic and molecular analyses on the bacteria found within the gill tissue of

30 Bathymodiolus mussels (Mytilidae, Bathymodiolinae) that were discovered at the Lost

31 City. Here we show that Lost City mussels harbour chemoautotrophic and

32 methanotrophic endosymbionts simultaneously. Furthermore, populations of the

33 chemoautotrophic symbionts from the Lost City and two sites along the MAR are

34 genetically distinct from each other, which suggests spatial isolation of bacteria in the

35 deep-sea. These findings provide new insights into the processes that drive

36 diversification of bacteria and evolution of symbioses at hydrothermal vents. 
Introduction

Recent evidence suggests that microbial populations in spatially and chemically

fragmented habitats exhibit geographic structure (Whitaker et al., 2003; Papke et al., 2003) rather than being distributed ubiquitously as previously hypothesized (see Finlay 2002; Fenchel 2003). The patchy mosaic of populations in heterogeneous environments restricts gene flow, while promoting genetic differentiation and local adaptation (Slatkin 1987). Due to the heterogeneous nature of hydrothermal vent environments, chemosynthetic bacteria inhabiting vents probably have geographically structured populations as well. If so, this would have direct implications for how topographic features of the seafloor, deep-ocean currents, and chemically variable environments impact the evolution and diversity of bacteria, the origin and evolution of bacteria-vent invertebrate symbioses, and the assemblage of hydrothermal vent communities.

The fragmented distribution of deep-sea hydrothermal vents lies in stark contrast to the uniform conditions of the marine abyssal zone (Tunnicliffe, 1988, 1991; Tunnicliffe and Fowler, 1996; Van Dover, 2000). Discrete hydrothermal vent fields are comparable to islands, distributed in a spatially, chemically, and temporally patchy chain along the deep-sea ridges and remote, off-axis sites (Tunnicliffe, 1988, 1991;

54 Tunnicliffe and Fowler, 1996; Tunnicliffe et al., 1998; Van Dover et al., 2002).

Differences between ridges in geography, tectonic activity, age of spreading center, and 56 connectedness of ridge segments likely play a major role in regulating gene flow among populations (Vrijenhoek, 1997; Van Dover et al., 2002; Hurtado et al., 2003), the distribution of vent macrofauna (Van Dover, 1995; Tunnicliffe and Fowler, 1996; Juniper and Tunnicliffe, 1997), and the composition of ecological communities

60 (Tunnicliffe, 1991). For example, 'fracture zones' (Fig. 1) likely inhibit dispersal of 
61 larvae by separating ridge segments that are undergoing independent volcanic evolution

62 (Van Dover et al. 2002). Though associations between chemosynthetic bacteria and

63 their invertebrate hosts provide the basis for macrofaunal production at deep-sea

64 hydrothermal vents, almost nothing is known about the distribution of genetic variation

65 in the symbionts and how population structure of bacteria affects ecological interactions

66 and the evolution of symbioses at vents.

Most dominant vent macrofauna host endosymbiotic bacteria for the capture of

68

69 chemical energy, yielding a constant food source in this stochastic environment (Fisher, 1990; Cavanaugh et al., 2005; Stewart et al., 2005). Typically, the host provides the symbionts with simultaneous access to oxygen and reduced compounds, and the bacteria, in turn, supply the host with fixed carbon generated from $\mathrm{C}_{1}$ compounds. Along the Mid-Atlantic Ridge (MAR), vents are inhabited by two species of mussels, Bathymodiolus azoricus and B. puteoserpentis (Mytilidae; Bathymodiolinae), that host chemoautotrophic (energy source: reduced compounds such as $\mathrm{H}_{2} \mathrm{~S}$; carbon source: $\mathrm{CO}_{2}$ ) and methanotrophic (energy and carbon source: $\left.\mathrm{CH}_{4}\right) \gamma$-Proteobacteria within their gill tissue (Cavanaugh et al., 1992; Distel et al., 1995; Nelson et al., 1995; FialaMédioni et al., 2002). The unique capacity of some bathymodioline mussels to house dual endosymbionts permits the host to utilize multiple compounds for energy acquisition, allowing colonization of diverse environments (Distel et al., 1995; FialaMédioni et al., 2002; DeChaine and Cavanaugh, 2005).

The off-axis location, shallow depth $(\sim 800 \mathrm{~m})$, distinct chemical environment, and scarcity of known symbiont-hosting invertebrates at the Lost City Hydrothermal Field (LC) suggested the possibility that mussels discovered there (B. aff. azoricus, T. Shank unpublished data), host endosymbionts that are different from those on the MAR. 
85 For example, the vent fluids of the off-axis Lost City are relatively cool $\left(10-90^{\circ} \mathrm{C}\right)$, alkaline $(\mathrm{pH} \geq 10)$, methane-rich $\left(0.13-0.28 \mathrm{mmol} \mathrm{kg}^{-1}\right)$, and lie in stark contrast to the acidic, sulfide-rich effluent of the MAR vents $\left(200-360^{\circ} \mathrm{C}, \mathrm{pH}=3-5\right)$ that are $\sim 15 \mathrm{~km}$ east and $2200 \mathrm{~m}$ deeper (Kelley, et al., 2001, 2005). The abundance of methane and hydrogen and low availability of $\mathrm{H}_{2} \mathrm{~S}$ (due to the high $\mathrm{pH}$ of the fluids, given the pKa1 of $\mathrm{H}_{2} \mathrm{~S}=7.04$; Budavari 1996) at the LC suggested that mussels found therein might host primarily methanotrophs, and not thioautotrophs, which would be novel given that all known vent mussels in the Atlantic Ocean host dual symbionts. Furthermore, the apparent remoteness of the Lost City provided a unique setting to resolve whether symbiotic bacterial populations at hydrothermal vents are ubiquitous or structured. Answers to these questions provide a foundation for understanding the forces that promote genetic divergence among symbiont populations and thus determine the biogeography and evolution of bacteria.

The objectives of this study were to 1) determine if the bathymodioline mussels inhabiting the LC hosted symbiotic bacteria and 2) how the symbionts were related, both phylogenetically and demographically, to those hosted by mussels on the MAR. First, we employed transmission electron microscopy (TEM) to determined the presence and morphology of putative symbionts within the Lost City mussel gill tissue and then resolved the relationship of the Lost City symbionts with known symbiotic and freeliving bacteria using sequence data from the conserved 16S rRNA gene (Woese, 1987). The bathymodioline chemoautotrophs from the Lost City, and from two MAR fields, Lucky Strike and Snake Pit, were selected for additional population genetic analyses because: 1) bathymodiolines apparently acquire their chemoautotrophic symbionts from the environment each generation (Won et al., 2003), and thus serve as sampling vessels 
109 of the free-living bacterial population, 2) the chemoautotrophs only have one ribosomal

110 RNA operon, precluding concerns over non-orthologous genetic variation (Won et al.,

111 2003), and 3) chemoautotrophs are more widespread among invertebrate hosts at

112 hydrothermal vents than methanotrophic symbionts (Cavanaugh et al., 2005), thus

113 permitting broad genetic comparisons. An intraspecific phylogeny and the demographic

114 history of each chemoautotroph population (defined by location) were inferred from

115 sequence data of the rapidly evolving 16S-23S rRNA internal transcribed spacer (ITS;

116 Antón et al., 1998). By employing both conserved and highly variable markers, the

117 phylogenetic position of Lost City mussel symbionts was resolved at two scales, within

118 the $\gamma$-Proteobacteria and among populations of chemoautotrophs hosted by vent-

119 endemic mussels along the northern MAR.

\section{Results}

122 Characterization of the Lost City symbiosis

123 This characterization, which constitutes the first description of a symbiosis from

124 the LC, revealed two morphologically distinct Gram negative bacteria in the mussel

125 bacteriocytes, gill epithelial cells specialized for housing symbiotic bacteria (Fig. 2a).

126 As in other vent symbioses, the bacteriocytes were separated by symbiont-free

127 intercalary cells. Vacuoles within a bacteriocyte harbored either several coccoid bacteria

128 ( 0.3 $\mu \mathrm{m}$ in diameter $)$ or a single, large bacterium $(\sim 1.5-2.0 \mu \mathrm{m})$ exhibiting

129 intracytoplasmic membranes typical of type I methanotrophs (Fig 2b). Based on the

130 characteristics of endosymbionts in other bathymodioline mussels (Cavanaugh et al.,

131 1992; Fiala-Médioni et al., 2002; Robinson et al., 1998), the small and large bacteria

132 were inferred to be chemoautotrophs and methanotrophs, respectively. 
134 observations of dual endosymbionts in the Lost City mussels. First, sequence

135 alignments revealed that the symbiont phylotypes from the Lost City (Genbank

136 accession numbers A and B) were identical to two phylogenetically distinct lineages of

$137 \gamma$-Proteobacteria, a chemoautotroph and a methanotroph, previously found in both $B$.

138 azoricus and B. puteoserpentis on the MAR. The presence of both phylotypes in the gill

139 tissue of these two MAR mussel species has been verified through in situ hybridization

140 with phylotype-specific probes (Distel et al., 1995; Duperron et al., 2005). In our

141 analyses, chemoautotrophic and methanotrophic symbionts of the mussels formed

142 separate, well-supported monophyletic clades that were nested with chemoautotrophs of

143 vent-endemic vesicomyid clams and free-living methanotrophs, respectively (Fig. 3).

144 This finding demonstrates the tight ecological and historic specificity of the interaction

145 between the mussels and two distinct subsets of the $\gamma$ Proteobacteria. While both

146 Bayesian and maximum parsimony analyses inferred similar tree topologies, the deep

147 relationships among the mussel methanotroph, mussel and clam chemoautotroph, and

148 other symbiont clades remain uncertain (for $\alpha=0.05$ ). Finally, the occurrence of both

149 symbiont phylotypes across the 2-3 mussel species demonstrated a lack of host fidelity

150 and implied that both methanotrophs and chemoautotrophs were acquired from the local

151 environment.

152 All mussel individuals harboured several, distinct chemoautotrophic symbiont

153 ITS-genotypes (Genbank accession numbers X through Y). Twenty-four percent of the

154 ITS-genotypes from Lucky Strike and 38\% from Snake Pit were shared among host

155 individuals within each of those localities (Fig. 4). In contrast, the two Lost City host

156 mussels had no chemoautotroph ITS-genotypes in common with each other, possibly 
157 owing to the small population size of mussels at that location. The occurrence of

158 multiple, geographically restricted chemoautotroph ITS-genotypes within an individual

159 host reinforced the contention that each individual mussel acquired its symbionts from

160 the local, free-living bacterial community as shown by the distribution of 16S rRNA

161 phylotypes in this study and previous analyses of ITS variation (Won et al., 2003).

162

Biogeography of bathymodioline chemoautotrophic endosymbionts

Analyses of ITS sequence data showed that the chemoautotrophic symbionts of

165 bathymodioline mussels were not distributed ubiquitously, but rather exhibited

166 population structure associated with geographic location. This finding, which contrasts

167 with the observed ubiquity of the 16S rRNA phylotype (above and Duperron et al., 168 2005), underscores the need to use highly variable markers in analyses at the population

169 level. The genetic variation in the ITS region (1.05\% average pair-wise sequence

170 divergence) permitted resolution of evolutionary relationships among populations of

171 chemoautotrophic symbionts at hydrothermal fields. Two distinct ITS-clades of

172 chemoautotrophs were separated by 13 nucleotide substitutions: the Bathymodiolus

173 puteoserpentis (Snake Pit) symbionts and the B. azoricus - B. aff. azoricus clade, which

174 included symbionts from both Lucky Strike and the Lost City (Fig. 4). Furthermore, the

175 overall estimates of $\theta(=6.9)$ and $\mathrm{T}(=1.6)$ from MDIV imply that the northern and

176 southern populations of Bathymodiolus chemoautotrophic symbionts in the north

177 Atlantic (as defined by the ITS-clades) are large and historically have been separated

178 from one another.

179 Our genetic analyses revealed that populations of chemoautotrophic symbionts

180 inhabiting different hydrothermal vent fields were isolated and experienced independent 
181 demographic histories. First, populations of chemoautotrophs at the Lost City and

182 Lucky Strike were more genetically diverse, as estimated by $\theta$ based on the number of

183 segregating sites (W) and the average pair-wise nucleotide diversity $(\pi)$ for haploid

184 genomes, than the population at Snake Pit (Table 1). Moreover, Tajima's D tests of

185 neutrality suggest that the populations at the Lost City and at Lucky Strike have been

186 demographically stable, whereas the symbionts at Snake Pit likely experienced a

187 population bottleneck (a reduction in population size followed by rapid population

188 growth; Table 1). We cannot rule out, however, the possibility of a selective sweep for

189 Snake Pit symbionts, because Tajima's D does not effectively differentiate between

190 population processes and selection (Tajima 1989). Finally, based on $\mathrm{F}_{\mathrm{ST}}$ estimates of

191 isolation, our analyses revealed genetic divergence among populations of

192 chemoautotrophic symbionts at all study locations, irrespective of host species (Table 2)

193 or distance between sites (no isolation-by-distance, $\mathrm{p}=0.9$ ).

194

\section{Discussion}

196 Though the LC lies distantly off-axis and has a novel chemical environment

197 (Kelley, et al., 2001, 2005), mussels in the genus Bathymodiolus found at the Lost City

198 host dual symbionts, a methanotroph and a chemoautotroph, with identical 16S rRNA

199 phylotypes as those along the Mid-Atlantic Ridge (MAR). This result is unexpected

200 given the paucity of $\mathrm{H}_{2} \mathrm{~S}$ (due to the high $\mathrm{pH}$ ) in the effluent of Lost City vents (D.

201 Butterfield pers. comm.) and raises the question of whether the chemoautotrophs are

202 using sources of energy other than sulfur compounds, such as hydrogen that is abundant

203 at the vent fluids. Indeed, alternate energy sources may be used by many symbionts, as

204 only B. thermophilus found along the Eastern Pacific Rise have been shown to use 
sulfur (Belkin et al. 1986; Nelson et al. 1995). The discovery and characterization of the

Lost City bathymodioline symbionts, in light of the diversity of chemical environments inhabited by mussels, underscores the ecological and evolutionary stability of the dual symbiosis.

The occurrence of single phylotypes, for both the chemoautotroph and the

210 methanotroph, across different host species demonstrated that neither of the symbiont

211 types was host species-specific. A similar lack of host-species fidelity was shown for

212 the chemoautotrophic endosymbionts of hydrothermal vent tubeworms that were

213 inferred to be environmentally transmitted (Feldman et al., 1997; Nelson and Fisher,

214 2000; reviewed in Cavanaugh et al., 2005). Our analyses revealing the broad

215 distribution of symbiont phylotypes across multiple host species suggest that both

216 methanotrophs and chemoautotrophs of mussels in the northern Atlantic are acquired

217 from the environment, rather than being transmitted from mother to offspring each

218 generation as for the closely related chemoautotrophs of another vent bivalve,

219 Calyptogena magnifica (Cary and Giovannoni, 1993). This finding implies that mussels

220 acquire symbionts from the local community when they colonize a site and has implications for local adaptation of symbionts to that environment.

Chemoautotrophic symbiont populations hosted by bathymodioline mussels were inferred to be isolated from each other because no ITS-genotypes were shared among the three hydrothermal fields. Since B. azoricus individuals at the Broken Spur hybrid zone on the MAR (just south of the Lost City) harboured symbionts from both northern (B. azoricus) and southern (B. puteoserpentis) ITS-clades (Won et al., 2003), it is unlikely that the host organisms affected the distribution of ITS genotypes, though the host may have selected for certain bacterial phylotypes from the local free-living 
229 population. Because the chemical environment of the Lost City is drastically different

230 from both vent sites on the MAR (Kelley et al. 2001), and symbiont populations from

231 Lost City and Lucky Strike are closely related phylogenetically while those from the

232 two MAR sites are not, the chemical environment may not be a large factor in

233 governing the distribution of bathymodioline symbionts. Rather, geography probably

234 played a major role in generating isolation among populations.

The three sites in this study are separated by fracture zones, depth, distance, and

deep ocean currents, all of which have been implicated as dispersal barriers that could promote genetic divergence among populations (Van Dover et al., 2002). Though the distance between the Lost City and Lucky Strike to the north $(1253 \mathrm{~km})$ is greater than the distance between the Lost City and Snake Pit to the south $(832 \mathrm{~km})$, the Lost City chemoautotrophs cluster with those in the north (Fig. 4). Thus, we inferred that distance

241 did not have as large an effect on isolation as did topographic features that likely

242 influence deep-ocean currents. For instance, the two ITS-clades (Fig. 4) are

243 geographically separated by many transform faults that offset the spreading axis,

244 including the $\sim 6000 \mathrm{~m}$ deep Atlantis Fracture Zone, just to the south of the Lost City and the Kane Fracture Zone just north of Snake Pit (Fig. 1). Smaller fracture zones, such as the Oceanographer Fracture Zone to the north, are apparently not as strong of barriers

247 to dispersal, but this remains to be evaluated. Thus, understanding the biogeographic

248 history of bacteria that inhabit hydrothermal vents provides an empirical basis for and

249 an independent means of assessing models of deep-ocean currents.

250 Isolation among hydrothermal vent fields has likely led each population of 251 chemoautotrophic symbionts to experience independent demographic histories, as 252 inferred through differences in $\theta$, Tajima's D tests of neutrality, and the high levels of 
253 isolation estimated by $\mathrm{F}_{\mathrm{ST}}$. Because the $16 \mathrm{~S}-\mathrm{ITS}-23 \mathrm{~S}$ spacer is mostly comprised of

254 seemingly functionless regions (Antón et al., 1998), the possibility that selection caused

255 the observed patterns of genetic variation is unlikely. Rather, the demographic history of 256 a symbiont population may depend on the tectonic activity at the site, which, in addition

257 to supplying the bacteria with reduced compounds for energy production, could

258 decimate the population in an intense eruption. For example, we inferred that the 259 population of chemoautotrophic symbionts at Snake Pit was unstable, while the other 260 two populations were at equilibrium. A long-lived hydrothermal vent field, such as the 261 Lost City (Früh-Green et al., 2003) may maintain a heterogeneous and stable population 262 of chemoautotrophs, while shorter-lived or more eruptive sites may generate greater 263 fluctuations in population size and thus reduce genetic diversity.

264 Our findings fit with the biogeographic model for macrofauna larvae outlined by

265 Van Dover et al. (2002), which states that the greater degree of faulting along slow-

266 spreading ridges (e.g., the MAR) should serve to isolate populations. Since symbionts

267 are acquired from the local environment each generation, the host likely plays little role

268 in determining the distribution of genetic variation in bacterial populations among

269 locations. Rather, the strong divergence between northern and southern symbiont

270 populations and the lack of isolation-by-distance among localities demonstrated that

271 geographic barriers to dispersal, such as faulting, depth, and other topographic features

272 of the seafloor, divide bacterial populations. Also, though off-axis sites may be remotely

273 located, they may be connected (or have a historic connection) via deep-ocean currents

274 with sites along the ridge, as indicated by the Lost City populations clustering with

275 those of Lucky Strike. We conclude that topography is a major influence on the

276 distribution of diversity among populations of symbiotic bacteria at hydrothermal vents, 
277 and that additional research is needed to clarify how differences among ridges in

278 tectonic activity, geography, and physical oceanography have impacted the population

279 structure of symbiotic bacteria and at what scale.

280 Resolving how populations of bacterial endosymbionts are structured has

281 important implications for microbial biogeography, bacterial diversity and evolution,

282 the origin and evolution of prokaryote-eukaryote symbioses, and the ecology and

283 evolution of life at deep-sea hydrothermal vents. First, studies in microbial

284 biogeography have revealed that limits to gene flow might yield geographic structure

285 within microbial taxa (Papke et al. 2003; Whitaker et al. 2003; Kirchman et al., 2005).

286 Population subdivision implies an increased potential for local adaptation and lineage

287 diversification. Until now, genetic structure and potential for local adaptation in

288 chemosynthetic endosymbionts have remained uncertain. Environmentally transmitted

289 endosymbionts are expected to respond to abiotic selective forces in the environment as

290 well as experience gene transfer with the hydrothermal vent free-living bacterial

291 community. This will not only impact the genetic diversity of symbionts, but may

292 ultimately affect the fitness of the invertebrate host. This and future studies on the

293 biogeography of symbionts inhabiting deep-sea hydrothermal vents, including

294 comparisons with the free-living bacterial community, host biogeography, and among-

295 site variation in environmental factors, will provide a basis for understanding the

296 processes responsible for the diversification of bacteria and symbioses on this planet.

298 Experimental Procedures

299 Specimen collection 
301 hydrothermal vent field $\left(30^{\circ} 07.40^{\prime} \mathrm{N}, 42^{\circ} 07.24^{\prime} \mathrm{W} ; 800 \mathrm{~m}\right.$ deep) and from the Lucky

302 Strike $\left(37^{\circ} 17.26^{\prime} \mathrm{N}, 32^{\circ} 16.50^{\prime} \mathrm{W} ; 1693 \mathrm{~m}\right.$ deep) and Snake Pit $\left(23^{\circ} 22.10^{\prime} \mathrm{N}\right.$, $44^{\circ} 56.91^{\prime} \mathrm{W} ; 3492 \mathrm{~m}$ deep) vent sites on the MAR (Fig. 1). Specimens were preserved

304 for ultrastructural analysis or stored at $-80^{\circ} \mathrm{C}$. Symbiont-bearing gill tissue was fixed,

305 embedded, and examined by transmission electron microscopy (Distel et al., 1995).

306 DNA was extracted from the frozen gill tissue of the two Lost City mussels, 20

307 individuals of Bathymodiolus azoricus from Lucky Strike and 20 of B. puteoserpentis

308 from Snake Pit with DNeasy Tissue Extraction Kits (Qiagen, Valencia, CA).

Genetic sampling and analyses

To resolve evolutionary relationships, the symbiont(s) 16S rRNA gene was

313 amplified using the universal bacteria primers $27 \mathrm{f}$ and $1492 \mathrm{r}$ (Weisburg et al., 1991),

314 from multiple specimens of the three vent sites, gel purified (Qiagen Gel Extraction

315 Kit), and cloned (TOPO TA Cloning Kit; Invitrogen Corp., Frederick, MD). Thirty-two 316 clones per host population were analyzed (16 for each of the two mussels from the Lost

317 City and two clones for each of 16 mussels at both the Lucky Strike and Snake Pit

318 sites). The legitimacy of point mutations in all unique phylotypes was evaluated using

319 ARB (Ludwig et al., 2004) by assessing complementary base pairing on the 16S rRNA

320 secondary structure and by following the sequence conservation rule (Acinas et al., $3212004)$.

To estimate within- and among-population genetic variation, sequence data from 323 the polymorphic 16S-ITS-23S region of the chemoautotrophs was used. The marker was 
amplified using two symbiont-specific primer combinations: Sym-ITS-830F and SymITS-23SR; Sym-ITS-1322F and Sym-ITS-23SR (Won et al., 2003). The former primer set was used to confirm symbiont species identification, because it yielded an 1800 nucleotide sequence including approximately $600 \mathrm{bp}$ of $16 \mathrm{~S}$ rRNA. The latter pair provided the ITS sequences for population genetic analyses. Ninety clones from the Sym-ITS-1322F and Sym-ITS-23SR amplicons were sequenced from each of the two Lost City mussels. For both the Lucky Strike and Snake Pit populations, 143 clones were sequenced from 20 host individuals.

333 primer pair, the BigDye Terminator v3.1 Cycle Sequencing Kit (Applied Biosystems,

334 Atlanta, GA), cleaned with Performa DTR 96-well Std. Plate Kit (Edge BioSystems,

335 Gaithesburg, MD), and sequenced on an ABI 3730 Gene Analyzer. Sequences were

336 edited in Sequencher 4.1.2 (Gene Codes Corp.), aligned in ClustalX (Thompson et al.,

337 1997), and alignments were manually edited in MacClade 4.0 (Maddison and Maddison, 338 2003).

The phylogenetic relationships among the 1303 bp portion of the $16 \mathrm{~S}$ rRNA

340 phylotypes from this and previous studies of bathymodioline symbionts (with

341 Escherichia coli as an outgroup; see Table 3 for Genbank accession numbers) were

342 inferred using maximum parsimony in PAUP 4.10b (Swofford, 2003) and Bayesian

343 posterior probabilities implemented with MrBayes v3.0b4 (Huelsenbeck and Ronquist, 344 2001). Maximum parsimony trees were generated on PAUP 4.10b (Swofford, 2003),

345 with heuristic searches, random sequence addition with 100 replicates, and TBR branch 346 swapping. Significance was determined from a 1000 replicate bootstrap analysis using 347 the same search parameters. From the Bayesian analysis, using four-chain Metropolis- 
348 coupled Markov chain Monte Carlo (MCMCMC) analysis, a consensus tree of 11,000

349 post burn-in sampled trees was generated in PAUP 4.10b (Swofford, 2003). Both

350 Bayesian and parsimony analyses yielded similar inferences of evolutionary history.

351 Intraspecific phylogenies were inferred from the ITS sequences for the

352 chemoautotrophic symbionts using parsimony implemented in the TCS software

353 package (Clement et al., 2000) and a combination of Bayesian and maximum likelihood

354 analyses. Eighty-five nucleotides of tRNA-Ala and $77 \mathrm{bp}$ of tRNA-Ile occurred within

355 the 16S-ITS-23S sequence. The $1200 \mathrm{bp}$ of ITS included five indels at positions 361-

$356364,542-543,711,937-939$, and 966-982, which were each transformed into a single

357 polymorphic position (Widmer and Baltisberger, 1999). After converting the indels to

358 one base substitution each, 48 polymorphic sites were described for the remaining 1178

359 bp, of which 36 sites were parsimony informative. For the Bayesian analysis, post burn-

360 in trees were imported into PAUP 4.10b (Swofford, 2003) and sorted to choose the

361 maximum likelihood tree. The parsimony and maximum likelihood trees were similar

362 and the few differences did not affect any conclusions.

363 Within-population genetic variation and among-population genetic

364 differentiation were estimated to test the relationships between the Lost City

365 chemoautotrophic endosymbionts and the two populations on the MAR. All measures

366 were averaged across individuals from the population to account for potential PCR bias.

367 First, an overall measure of genetic diversity for haploid genomes $(\theta=2 \mathrm{Ne} \mu)$ for all

368 populations and the amount of genetic divergence $(\mathrm{T})$ between northern and southern

369 clades (see Results) were estimated using MDIV (Nielsen and Wakeley 2001) assuming

370 the HKY finite sites model and running the coalescent simulations three times for each

371 species to evaluate convergence for each parameter. Within-population genetic diversity 
372 was estimated based on the average pair-wise nucleotide diversity $\left(\theta_{\pi}\right)$ and the number

373 of segregating sites $\left(\theta_{\mathrm{W}}\right)$ for haploid genomes (e.g., Herbeck et al., 2003). In addition,

374 both estimators of $\theta$ should be equivalent in a population at equilibrium that is evolving

375 neutrally. Tajima's D was used to compare the two estimators of $\theta$ and examine whether

376 populations were at equilibrium (Tajima, 1989). To test whether or not populations of

377 bacterial symbionts were isolated, the mean pair-wise differences and degree of

378 differentiation $\left(\mathrm{F}_{\mathrm{ST}}\right)$ among locations were estimated (e.g., Whitaker et al., 2003).

379 Isolation-by-distance was tested (Rousset, 1997), with distances among sites as follows:

380 Lost City to Lucky Strike (1253 km), Lost City to Snake Pit (832 km), and Lucky Strike

381 to Snake Pit $(2037 \mathrm{~km})$. All analyses were performed using Arlequin 2.0 (Schneider et

382 al., 2000). 
383 Acknowledgements

384 We express our deep appreciation to the captain and crews of the R/V Atlantis

385 and DSV Alvin for their immeasurable assistance in specimen collection (OCE

386 0136871, T. Shank). The sequencing and analyses were funded by an NSF Microbial

387 Biology Postdoctoral Fellowship for E. G. DeChaine (DBI-0400591) and NSF grants

388 for C. M. Cavanaugh (OCE-0453901, DEB-0089738). For sample collections and

389 unpublished sequence data the authors would like to thank Z. McKiness. We would also

390 like to thank D. Stahl and three anonymous reviewers for their constructive feedback.

391

392 
392

393

394

395

396

397

398

399

400

401

402

403

404

405

406

407

408

409

410

411

412

413

414

415

\section{References}

Acinas, S. G., V. Klepac-Ceraj, D. E. Hunt, C. Pharino, I. Ceraj, D. L. Distel, M. F. Polz. 2004. Fine-scale phylogenetic architecture of a complex bacterial community. Nature 430: 551-554.

Antón, A. I., A. J. Martínez-Murcia, F. Rodríguez-Valera. 1998. Sequence diversity in the $16 \mathrm{~S}-23 \mathrm{~S}$ intergenic spacer region (ISR) of the rRNA operons in representatives of the Escherichia coli ECOR collection. J. Mol. Evol. 47: 62-72.

Belkin, S., D. C. Nelson, and H. W. Jannasch. 1986. Symbiotic assimilation of $\mathrm{CO}_{2}$ in two hydrothermal vent animals, the mussel Bathymodiolus thermophilus and the tubweorm Riftia pachyptila. Biol. Bull. 170: 110-121.

Budavari, S. 1996. The Merck Index - An Encyclopedia of Chemicals, Drugs, and Biologicals. Whitehouse Station, NJ: Merck and Co., Inc., p. 823.

Cary, S. C. and S. J. Giovannoni. 1993. Transovarial inheritance of endosymbiotic bacteria in clams inhabiting deep-sea hydrothermal vents and cold seeps. Proc. Natl. Acad. Sci. USA. 90: 5695-5699.

Cavanaugh, C. M., C. Wirsen, and H. J. Jannasch. 1992. Evidence for methylotrophic symbionts in a hydrothermal vent mussel (Bivalvia: Mytilidae) from the MidAtlantic Ridge. Appl. Environ. Microbiol. 58: 3799-3803.

Cavanaugh, C.M., Z.P. McKiness, I.L.G. Newton, and F.J. Stewart. 2005. Marine chemosynthetic symbioses. In M. Dworkin et al., Eds., The Prokaryotes: An Evolving Electronic Resource for the Microbiological Community, SpringerVerlag, New York.

Clement, M., D. Posada, K. A. Crandall. 2000. TCS: a computer program to estimate gene genealogies. Molec. Ecol. 9: 1657-1659. 
416 DeChaine, E. G. and C. M. Cavanaugh. 2005. Symbioses of methanotrophs and deepsea mussels (Mytilidae: Bathymodiolinae). In J. Overmann, Ed., Molecular Basis of Symbiosis, Sinauer Assoc. In press.

Distel, D., H. K. Lee, and C. M. Cavanaugh. 1995. Intracellular coexistence of methano- and thioautotrophic bacteria in a hydrothermal vent mussel. Proc. Natl. Acad. Sci. USA. 92: 9598-9602.

Duperron, S. C. Bergin, F. Zielinski, Z. P. McKiness, E. G. DeChaine, M. Sibuet, C. M. bathymodioline mussels (Bivalvia: Mytilidae) from the Mid-Atlantic Ridge. Environ. Microbiol. In review.

Feldman, R., Black, M., Cary, C., Lutz, R., and R. Vrijenhoek. 1997. Molecular phylogenetics of bacterial endosymbionts and their vestimentiferan hosts. Molec. Mar. Biol. Biotech. 6: $268-277$.

Fenchel, T. 2003. Biogeography for bacteria. Science 301: 925-926.

430 Fisher, C. R. 1990. Chemoautotrophic and methanotrophic symbioses in marine invertebrates. Rev. Aqua. Sci. 2: 399-436.

432 Fiala-Médioni, A., Z. McKiness, P. Dando, J. Boulegue, A. Mariotti, A. Alayse-Danet, J. Robinson, and C. Cavanaugh. 2002. Ultrastructural, bioghemical, and immunological characterization of two populations of a new species of Mytilid mussel, Bathymodiolus azoricus, from the Mid-Atlantic Ridge: evidence for a

437 Finlay, B. J. 2002. Global dispersal of free-living microbial eukaryote species. Science 296: 1061-1063. 
439 Früh-Green, G. L., D. S. Kelley, S. M. Bernasconi, J. A. Karson, K. A. Ludwig, D. A.

440 Butterfield, C. Boschi, and G. Proskurowski. 2003. 30,000 years of

$441 \quad$ hydrothermal activity at the Lost City vent field. Science 301: 495-498.

442 Herbeck, J. T., D. J. Funck, P. H. Degnan, \& J. J. Wernegreen. 2003. A conservative 443 test of genetic drift in endosymbiotic bacterium Buchnera: Slightly deleterious 444 mutations in the chaperonin groEL. Genetics 165: 1651-1660.

445 Huelsenbeck, J. P. \& Ronquist, F. 2001. MrBayes: Bayesian inference of phylogenetic trees. Bioinformatics 17, 754-755.

447 Hurtado, L. A., m. Mateos, R. A. Lutz, and R. C. Vrijenhoek. 2003. Coupling of bacterial endosymbiont and host mitochondrial genomes in the hydrothermal vent clam Calyptogena magnifica. Applied Environ. Microbiol. 69: 2058-2064.

Juniper, S. K. and V. Tunnicliffe. 1997. Crustal accretion and the hot ecosystem. Philos. Trans. R. Soc. Lond. A 355: 450-474.

Kelley, D. S., J. A. Karson, D. K. Blackman, G. L. Früh-Green, D. A. Butterfield, M. D. Lilley, E. J. Olson, M. O. Schrenk, K. K. Roe, G. T. Lebon, P. Rivizzigno, and the AT3-60 Shipboard Party. 2001. An off-axis hydrothermal vent field near the Mid-Atlantic Ridge at $30^{\circ} \mathrm{N}$. Nature 412: 145-149.

Kelley, D. S., Karson, D. K., Früh-Green, G. L., Yoerger, D. R., Shank, T. M., Butterfield, D. A., Hayes, J. M., Schrenk, M. O., Olson, E. J., Proskurowski, G., Jakuba, M., Bradley, A., Larson, B., Ludwig, K., Glickson, D., Buckamn, K., Bradley, A. S., Brazelton, W. J., Roe, K., Elend, M. J., Delacour, A., Baernasconi, S. M., Lilley, M. D., Baross, J. A., Summons, R. E., and S. P. Sylva. 2005. A serpentinite-hosted ecosystem: The Lost City Hydrothermal Field. Science 307: 1428-1434. 
463 Kirchman, D. L., Dittel, A. I., Malmstrom, R. R., and M. T. Cottrell. 2005. Biogeography of major bacterial groups in the Delaware estuary. Limnol. Oceanog. 50: 1697-1706.

465

466

467

468

469

470

471

472

473

474

475

476

477

478

479

480

481

482

483

484

Ludwig, W., O. Strunk, R. Westram et al. 2004. ARB: a software environment for sequence data. Nucleic Acid Res. 32: 1363-1371.

Maddison, D. R. and W. P. Maddison. 2000. MacClade 4. Sinauer Assoc. Inc. Sunderland, MA.

Nelson, D. C. and C. R. Fisher. 2000. Absence of cospeciation in deep-sea vestimentiferan tubeworms and their bacterial endosymbionts. Symbiosis. 28: 115.

Nelson, D. C., K. D. Hagan, and D. B. Edwards. 1995. The gill symbiont of the hydrothermal vent mussel Bathymodiolus thermophilus is a psychrophilic, chemoautotrophic, sulfur bacterium. Mar. Biol. 121: 487-495.

Nielsen, R., and J. W. Wakeley. 2001. Distinguishing migration from isolation: and MCMC approach. Genetics 158: 885-896.

Papke, R. T., N. B. Ramsing, M. M. Bateson, and D. M. Ward. 2003. Geographical isolation in hot spring cyanobacteria. Environ. Microbiol. 5: 650-659.

Robinson, J. J., M. F. Polz, A. Fiala-Médioni, and C. M. Cavanaugh. 1998. Physiological and immunological evidence for two distinct C-1-utilizing pathways in Bathymodiolus puteoserpentis (Bivalvia: Mytilidae), a dual endosyumbiotic mussel from the Mid-Atlantic Ridge. Mar. Biol. 132: 625-633.

Rousset, F. 1997. Genetic differentiation and estimation of gene flow from F-statistics under isolation by distance. Genetics 145: 1219-1228. 
485 Schneider, S., D. Roessli, and L. Excoffier. 2000. ARLEQUIN, a Software Package for Population Genetics Data Analysis, Version 2.0. Genetica and Biometry Laboratory, Univ. of Geneva. Geneva, Switzerland.

Slatkin, M. 1987. Gene flow and the geographic structure of natural populations. Science 236: 787-792.

Stewart, F. J., I. L. G. Newton, and C. M. Cavanaugh. 2005. Chemosynthetic endosymbioses: adaptations to oxic-anoxic interfaces. Trends Microbiol. 13: $439-448$.

Swofford, D. L. 2003. PAUP*. Phylogenetic Analysis Using Parsimony (*and Other Methods). Sinauer Associates, Sunderland, MA.

Tajima, F. 1989. The effect of change in population size on DNA polymorphism. Genetics 123: 597-601. alignment aided by quality analysis tools. Nucl. Acid Res. 24: 4876-4882.

500 Tunnicliffe, V. 1988. Biogeography and evolution of hydrothermal-vent fauna in the eastern Pacific Ocean. Proc. R. Soc. Lond. B 233: 347-366.

Tunnicliffe, V. 1991. The biology of hydrothermal vents: Ecology and evolution. Oceanogr. Mar. Biol. Annu. Rev. 29: 319-407.

504 Tunnicliffe, V. and C. Fowler. 1996. Influence of sea-floor spreading on the global hydrothermal vent fauna. Nature 379: 531-533.

506 Tunnicliffe, V., A. G. McArthur, and D. Mchugh. 1998. A biogeographical perspective of the deep-sea hydrothermal vent fauna. Advances in Marine Biology 34: 353-442.

508 Van Dover, C. L. 1995. Ecology of Mid-Atlantic Ridge hydrothermal vents. In: Parson, 

Soc. Spec. Publ. 87: 257-294.

511 Van Dover, C. L. 2000. The Ecology of Deep-sea Hydrothermal Vents. Princeton Univ. Press. Princeton, N. J.

Van Dover, C. L., C. R. German, K. G. Speer, L. M. Parson, and R. C. Vrijenhoek. 2002. Evolution and biogeography of deep-sea vent and seep invertebrates. Science 295: 1253-1257.

Vrijenhoek, R. C. 1997. Gene flow and genetic diversity in naturally fragmented metapopulations of deep-sea hydrothermal vent animals. J. Heredity 88: 285-293.

Weisburg, W. G., S. M. Barns, D. A. Pelletier, and D. J. Lane. 1991. 16S ribosomal DNA amplification for phylogenetic study. J. Bacteriol. 173: 697-703.

Whitaker, R. J., S. W. Grogan, and J. W. Taylor. 2003. Geographic barriers isolate endemic populations of hyperthermophilic archaea. Science 301: 976-978.

Widmer, A. and M. Baltisberger. 1999. Extensive intraspecific chloroplast DNA (cpDNA) variation in the alpine Draba aizoides L. (Brassicaceae): haplotype relationships and population structure. Molec. Ecol. 8: 1405-1415.

Woese, C. R. 1987. Bacterial evolution. Microbiol. Reviews 51: 221-271. 2003. Environmental acquisition of thiotrophic endosymbionts by deep-sea 
529 Table 1. Summary statistics for ITS sequences from the three populations of

530 chemoautotrophic symbionts.

531

532 Location Host Species $\quad \theta_{\pi}(\mathrm{sd}) \quad \theta_{\mathrm{W}}(\mathrm{sd}) \quad$ Tajima's D

533 Lucky Strike B. azoricus $\quad 2.4(1.4) \quad 2.8(1.0) \quad-0.63$

534 Lost City $\quad$ B. aff. azoricus $2.3(1.4) \quad 2.5(0.8) \quad-0.23$

535 Snake Pit $\quad$ B. puteoserpentis $\quad 0.7(0.6) \quad 1.9(0.7) \quad-1.67^{*}$

536

537 Estimates of genetic diversity $(\theta)$ based on the average pair-wise sequence divergence

$538(\pi)$ and number of segregating sites (W) are shown, with standard deviations (sd).

539 Estimates of Tajima's D are given for each population $(*$ denotes $\mathrm{p}<0.01)$. 
540 Table 2. Pair-wise comparisons of populations of chemoautotrophs hosted by

541 bathymodioline mussels.

542

543

Mean pair-wise differences

544 Location Lucky Strike Lost City Snake Pit

545 Lucky Strike $\quad 1.2 \quad 11.7$

$546 \quad$ Lost City $\quad 0.34 \quad 12.4$

$547 \quad$ Snake Pit $\quad 0.89 \quad 0.89$

$548 \quad$ Population pair-wise $\mathrm{F}_{\mathrm{ST}}$

549

550 Mean pair-wise differences for chemoautotroph ITS sequences are shown above the

551 diagonal, and population pair-wise $\mathrm{F}_{\mathrm{ST}}$ values are given below. All $\mathrm{F}_{\mathrm{ST}}$ values are

552 significant.

553 
553 Table 3. List of bacteria and Genbank accession numbers used to generate the 16S

554 rRNA phylogeny for $\gamma$-Proteobacteria (Fig. 3).

555 Environment

Species

Genbank accession no.

556 Free-living bacteria

557

558

559

560

561

562

563

564

565

566

567

568

569

570

571

572

573

574

575 Chemoautotrophic symbionts

576 Host Taxonomy Host species
L48227

L40994

J01695

X67023

D86374

X72773

L20843

AF304195

L20841

$\mathrm{X} 72767$

L35540

AF150806

AF 150807

AF232713

X84316

Y11317

AF16046

Thiomicrospira thyasirae. 
577 Phylum Annelida

$578 \quad$ Oligochaeta

Inanidrilus leukodermatus

$\mathrm{U} 24110$

579

Olavius loisae

AF104472

$580 \quad$ Vestimentifera

Escarpia spicata

U77482

581

Lamellabrachia columna

U77481

582

Ridgeia piscesae

U77480

583

Riftia pachyptila

M99451

584 Phylum Mollusca

585 Bivalvia

$586 \quad$ Lucinidae

Codakia orbicularis

X84979

587

Lucina nassula

X84980

588

Lucinoma aequizonata

M99448

589 Mytilidae

Bathymodiolus aff. brevior

DQ077891

590

B. puteoserpentis

U29163

591

B. azoricus - puteoserpentis

AM083974 and this study

592

B. septemdierum

AB036709

593

B. thermophilus

M99445

594

B. sp. Gabon Margin

AJ745718

595

$B$. sp. Juan de Fuca

Z. McKiness unpub. data

596

Thyasira flexuosa

L01575

597 Vesicomyidae

Calyptogena elongata

AF035719

598

C. fossajaponica

AB044744

599

C. phaseoliformes

AF035724

600

C. kilmeri

AF035720 
601

602

603

604

605 Phylum Nematoda

606 Desmodoridae Laxus sp.

607

608 Methanotrophic symbionts

609 Host Taxonomy Host species

610 Phylum Mollusca

611 Bivalvia

612 Mytilidae

B. puteoserpentis $\mathrm{M}$

613

614

615

616

617

618

B. sp. Gabon Margin M
C. magnifica

AF035721

AF035723

AF035725

AF035726

$\mathrm{U} 241110$
U29164

AM083950 and this study

U05595

AB036711

AB036710

AJ745717

AJ745717 


\section{$618 \quad$ Figure Legends}

619 Figure 1. Map of study sites and the Mid-Atlantic Ridge (MAR). The collection sites, 620 including the Lost City, Lucky Strike, and Snake Pit vent fields, are designated by white

621 circles and labelled. The MAR and its dominant fracture zones (F. Z.) are highlighted

622 by black lines. Several fracture zones relevant to the discussion are also labelled to 623 emphasize the geographically discontinuous nature of the MAR.

625 Figure 2. Transmission electron micrographs of endosymbionts within the gill tissue of 626 a Lost City mussel. A. Chemoautotrophic (C) and type I methanotrophic (M) symbionts 627 within the apical portion of two bacteriocytes (bc) separated by a symbiont-free 628 intercalary cell (ic). Scale bar $=2 \mu \mathrm{m}$. B. Higher magnification of the two symbiont 629 morphotypes; note intracytoplasmic membranes of the type I methanotroph. Scale bar = $630 \quad 0.5 \mu \mathrm{m}$.

632 Figure 3. Phylogeny of chemoautotrophic and methanotrophic endosymbionts hosted by 633 bathymodioline mussels and free-living $\gamma$-Proteobacteria, inferred from 16S rRNA gene 634 sequences (1303 nucleotides). Posterior probabilities from 11,000 bayesian trees are 635 shown above branches (significant $\geq 95$ ) and bootstrap values based on 1000 maximum 636 parsimony replicates are given below the branches. The two phylotypes in this study ( $B$.

637 azoricus - B. puteoserpentis) are boxed in gray and lettered (C and $\mathrm{M})$ for 638 chemoautotrophs and methanotrophs, respectively. Furthermore, the two clades that 
639 include mussel symbionts are boxed and labelled (C and $\mathrm{M})$. All symbiotic bacteria are

640 labelled 'symbiont' while free-living bacteria are designated by taxonomic name alone.

641

642 Figure 4. Parsimony network inferred from 1200 nucleotides of rrn internal transcribed

643 spacer (ITS rRNA) genotypes from chemoautotrophic symbionts of Bathymodiolus

644 mussels collected from the Lost City, Lucky Strike, and Snake Pit hydrothermal fields.

645 ITS-genotypes are shown as circles, with size indicating relative frequency. Shading

646 denotes location and the distribution of genotypes within the host mussel population as

647 follows: Lucky Strike (black = genotypes found in $>1$ host individual, black

648 checkerboard $=$ genotypes restricted to only one host individual), Lost City (gray, no

649 symbionts were shared between the two host individuals), and Snake Pit (white =

650 genotypes found in $>1$ host individual, gray checkerboard $=$ genotypes restricted to only

651 one host individual). Lines connecting genotypes are one nucleotide difference. Small

652 black dots represent unsampled, hypothetical ancestors. LC1 and LC2 designate

653 genotype clades from the two individual Lost City mussels. Finally, the northern and

654 southern 'clades' are boxed and labelled $\mathrm{N}$ and S, respectively. 
655 Figure 1.

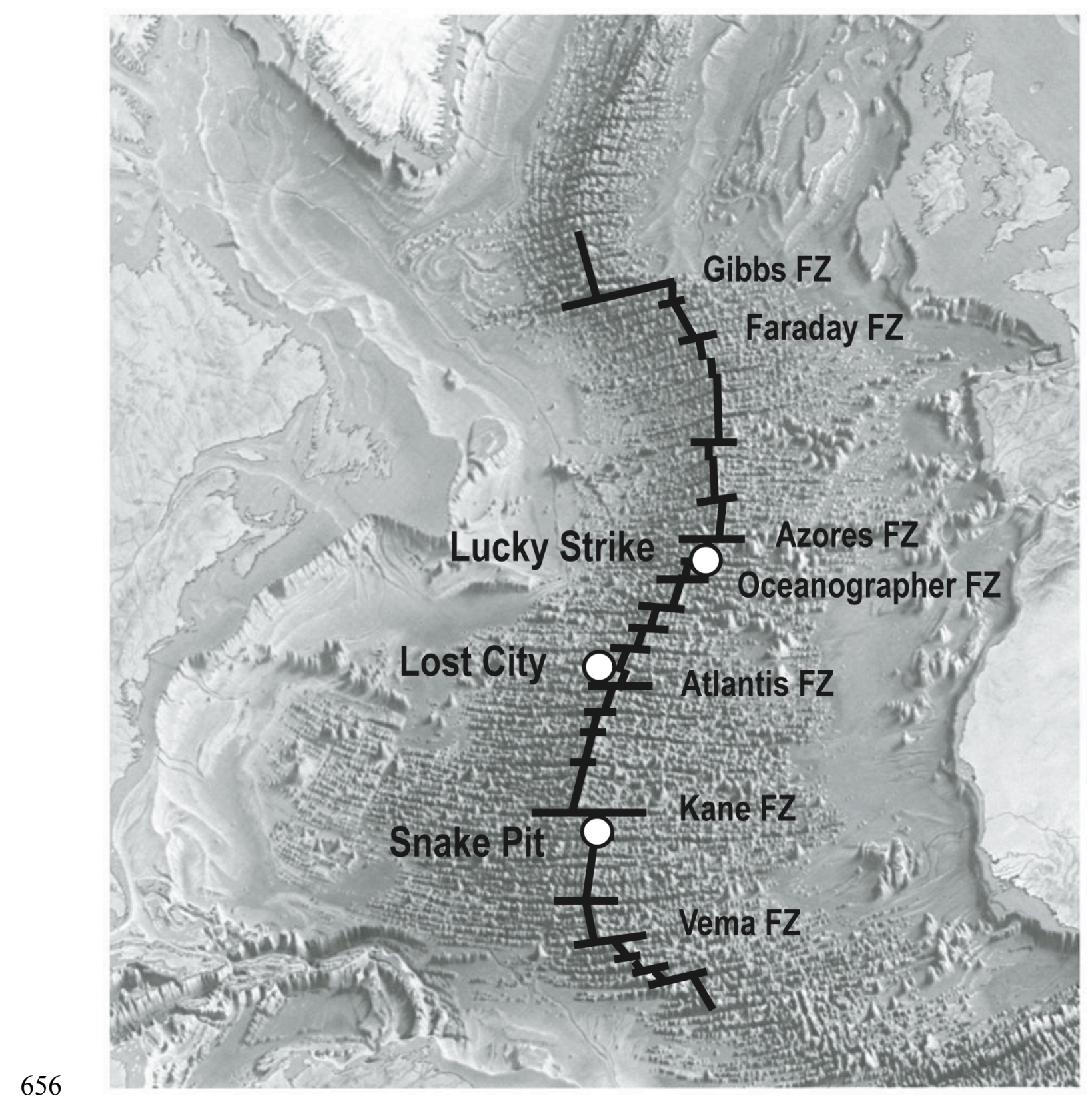

657 
Figure 2.
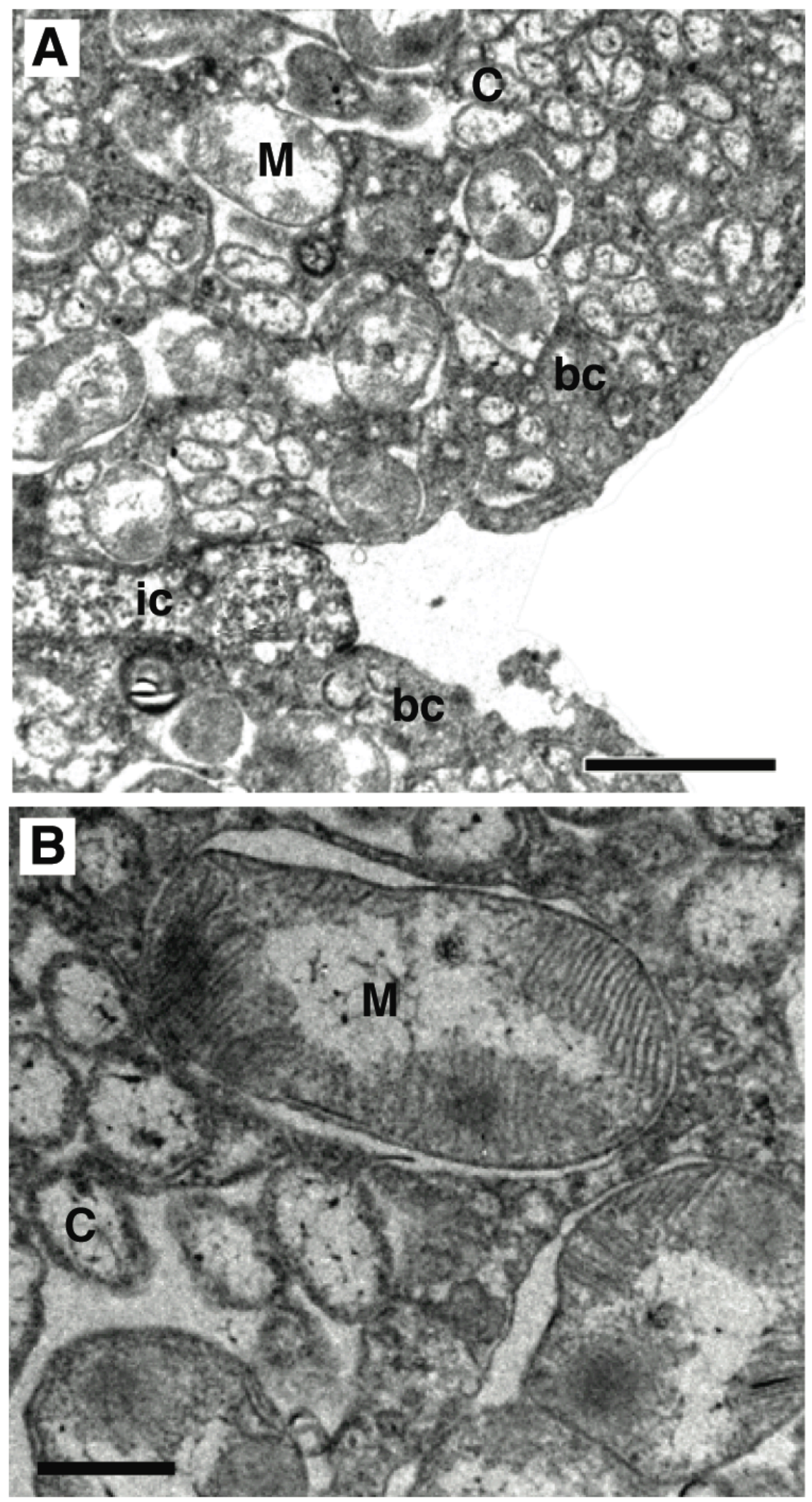
659 Figure 3.

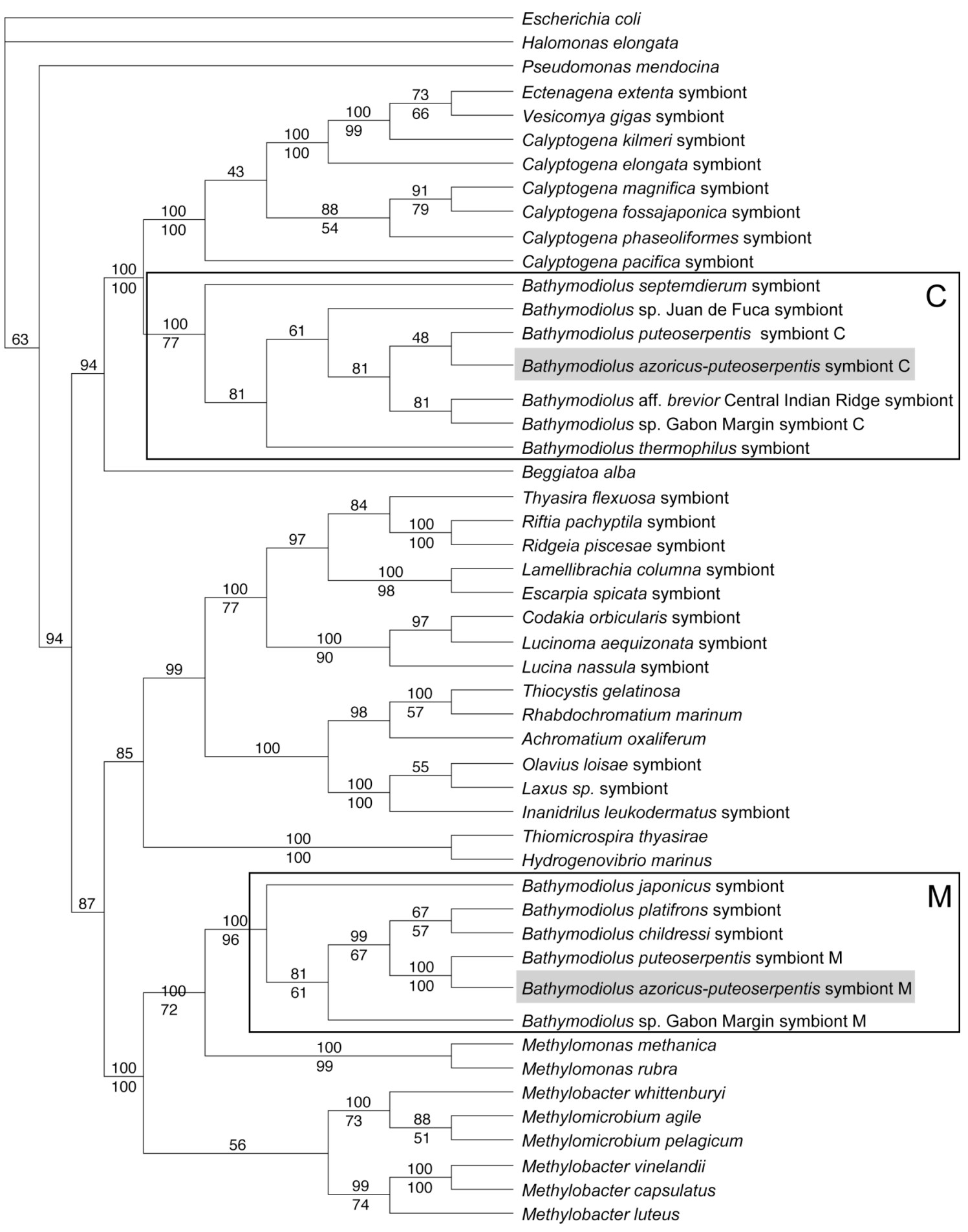


661 Figure 4.

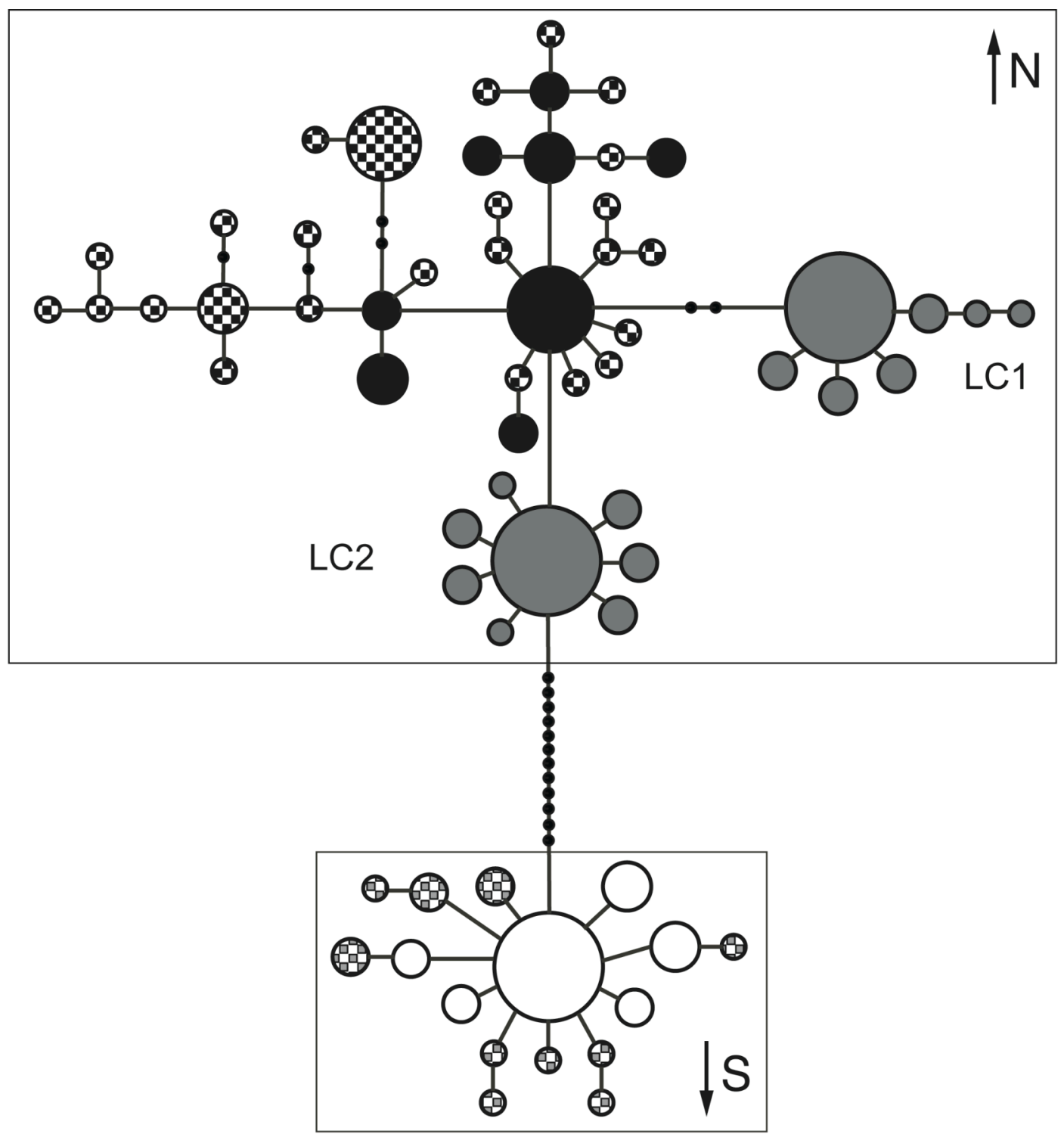

Genotype occurrence

Host Mussel 1 mussel $\geq 1$ mussel

Genotype Frequency

Lucky Strike

B. azoricus

$\Theta$

Lost City (LC)

$B$. aff. azoricus

n/a

1-2 $\quad 3-5 \quad 6-10 \quad 11-15 \quad 15-20$

$0 \bigcirc \bigcirc$

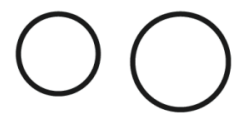

$\square^{21-50}$

Snake Pit

B. puteoserpentis (ㅇ)

0

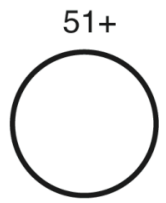

